\title{
The Effect of Alkaline Peroxide Pre-Treatment on Properties of Peanut Shell Powder Filled Recycled Polypropylene Composites
}

\author{
Nor Fasihah Zaaba*, Mariatti Jaafar and Hanafi Ismail \\ School of Materials and Mineral Resources Engineering, Universiti Sains \\ Malaysia, Engineering Campus, 14300 Nibong Tebal, Pulau Pinang, Malaysia \\ *Corresponding author: fasehazaaba@gmail.com
}

Published online: 15 April 2017

To cite this article: Nor Fasihah Zaaba, Mariatti Jaafar and Hanafi Ismail. (2017). The effect of alkaline peroxide pre-treatment on properties of peanut shell powder filled recycled polypropylene composites. Journal of Engineering Science, 13: 75-87, https://doi.org/10.21315/jes2017.13.6.

To link to this article: $\mathrm{https} / / / \mathrm{doi} . \mathrm{org} / 10.21315 / \mathrm{jes} 2017.13 .6$

\begin{abstract}
This recent study investigates the properties of recycled polypropylene $(R P P) /$ peanut shell powder (PSP) composites under the effect of alkaline peroxide pretreatment. RPP/PSP composites were prepared by melt-mixing and compression molding with 0 to $40 \mathrm{wt} \%$ of PSP loading. The untreated RPP/PSP composites and treated RPP/PSP $/ \mathrm{H}_{2} \mathrm{O}_{2}$ composites were compared and characterised by tensile properties, Fourier transform infrared (FTIR) spectroscopy, scanning electron microscopy (SEM) and thermogravimetric analysis (TGA). The results showed that the treated PSP enhanced the tensile and thermal properties of RPP/PSP/H $\mathrm{H}_{2} \mathrm{O}_{2}$ composites while the FTIR spectra and SEM morphology presented the elimination of lignin content strongly influenced the fractured surface and chemical characteristics of the RPP/PSP/H $\mathrm{H}_{2} \mathrm{O}_{2}$ composites.
\end{abstract}

Keywords: Lignocellulosic, alkaline peroxide, peanut shell powder, recycled polypropylene, lignin removal

\section{INTRODUCTION}

Natural fillers are acquiescent to modification as they enclose hydroxyl groups from lignin and cellulose. The interfaces or the effectiveness of natural fillers towards the matrix may possibly decrease due to the involvement of hydroxyl groups in hydrogen bonding within the cellulose molecules. Physical and mechanical properties of composites are relying on the interfaces. However, specific interfacial additives or chemical/physical treatments can be employed to enhance the interfacial adhesion by activate these groups and providing the new moieties that can efficiently interconnect between fillers and polymer matrix. ${ }^{1,2}$ 
Besides that, traditional chemical treatment such as extraction with benzene, alcohol, or $\mathrm{NaOH}$ (delignation and bleaching) also can be used. Different levels of achievement in enhancing strength, fitness and adhesion between fillers and matrix can be accomplished by various chemical modifications of natural fillers. Alkaline peroxide pre-treatment is one of the significant modifications of natural fillers by interference of hydrogen bonding in the network structure. Through this treatment, celluloses are depolymerised and short length crystallites are exposed while a certain amount of lignin, oils and wax that covering the external surface of the fillers cell wall are removed. ${ }^{3}$ The ionisation of hydroxyl groups to alkoxide are endorsed by the addition of aqueous sodium hydroxide $(\mathrm{NaOH})$ to natural fillers. ${ }^{4}$ Through this treatment, the exposure of celluloses on the fillers surface is increased and mechanical interlocking is improved. Meaning that, the number of possible reaction sites are increased, thus promotes natural fillers wetting. Furthermore, many studies on alkaline treatments have been done in order to increase the mechanical properties of polymer composites. For instance, John et al. investigated the effect of alkali treatment on properties of hybrid fillers composites. The results indicated that alkali treatment tends to increase the fillers surface area effectiveness in contacting the polymer matrix by breaking the fillers bundle into smaller size of fillers. ${ }^{5}$ Besides that, Sreekala et al. and Mukherjee et al. reported in their findings that the interfibrillar region becomes less dense and less rigid after the partial removal of lignin and hemicellulose by alkali modification of cellulose fillers. ${ }^{6,7}$ In this study, lignocellulosic PSP fillers were pre-treated with hydrogen peroxide to eliminate lignin prior to produce recycled polypropylene (RPP) composites. The tensile properties, Fourier transform infrared (FTIR) spectra, scanning electron microscope (SEM) images and thermogravimetric analysis (TGA) of recycled polypropylene (RPP) composites containing treated and untreated PSP at different filler loadings were compared.

\section{EXPERIMENTAL}

\subsection{Materials}

Recycled polypropylene (RPP) with melt flow index of $30 \mathrm{~g} / 10 \mathrm{~min}$, density of $0.896 \mathrm{~g} / \mathrm{cm}^{3}$, and tensile modulus of $900 \mathrm{MPa}$ was purchased from Zarm Scientific and Supplies, Pulau Pinang, Malaysia. Peanut shell powder (PSP) was also supplied by Zarm Scientific and Supplies, Pulau Pinang, Malaysia. Prior to composite fabrication, the peanut shells were ground to an average particle diameter of $66.84 \mu \mathrm{m}$ and dried for $3 \mathrm{~h}$ at $70^{\circ} \mathrm{C}$ using a vacuum oven. Sodium hydroxide $(\mathrm{NaOH})$, hydrogen peroxide $\left(\mathrm{H}_{2} \mathrm{O}_{2}\right)$ and acetic acid were obtained from Sigma Aldrich, Kuala Lumpur, Malaysia. 


\subsection{Pre-treatment of PSP by Alkaline Peroxide}

PSP was soaked in distilled water at a temperature of $65^{\circ} \mathrm{C}$ to $80^{\circ} \mathrm{C}$ for at least $12 \mathrm{~h}$ to eliminate the impurities and large particles. A total of $20 \mathrm{~g}$ of PSP was placed in a $500 \mathrm{~mL}$ flask containing $15 \mathrm{w} / \mathrm{v} \%$ of $\mathrm{NaOH}$. The flask was maintained at $75^{\circ} \mathrm{C}$ in a water bath with shaking at $40 \mathrm{rpm}$ for $3 \mathrm{~h}$ to remove lignin. Next, the PSP was washed several times with distilled water and treated with $2 \mathrm{w} / \mathrm{v} \%$ of $\mathrm{H}_{2} \mathrm{O}_{2}$ at $45^{\circ} \mathrm{C}$ and $40 \mathrm{rpm}$ for $8 \mathrm{~h}$. Continued reaction will remove more lignin content and activate the $\mathrm{OH}$ groups of the cellulose. The PSP was washed with distilled water and treated with $10 \mathrm{w} / \mathrm{v} \%$ of acetic acid at room temperature for 30 min to neutralise the excess $\mathrm{NaOH}$.

\subsection{Composite Preparation and Processing}

Two types of composites were prepared: RPP with untreated PSP (RPP/PSP) and RPP with $\mathrm{H}_{2} \mathrm{O}_{2}$-treated PSP (RPP/PSP/ $\mathrm{H}_{2} \mathrm{O}_{2}$ ). Both composites were prepared using an internal mixer (model R600/610 Rheomixmixer, Haake, Karlsruhe, Germany) at $180^{\circ} \mathrm{C}$ and $50 \mathrm{rpm}$ to obtain a homogeneous sample. The RPP was placed in the mixer and melted for 4 min before the PSP was added. The composites were mixed for another 8 min until the mixing torque stabilised. The total mixing time was $12 \mathrm{~min}$ for all samples. The processed samples were compression molded into a $1 \mathrm{~mm}$ thick sheet by an electrically heated hydraulic press (Kao Tieh Go Tech Compression Machine, Taichung, Taiwan) at temperature of $180^{\circ} \mathrm{C}$. Table 1 shows the formulation of each of the composites.

Table 1: Formulation of RPP/PSP and RPP/PSP- $\mathrm{H}_{2} \mathrm{O}_{2}$ composites

\begin{tabular}{lccc}
\hline Composite & $\begin{array}{c}\mathrm{RPP} \\
(\mathrm{wt} \%)\end{array}$ & $\begin{array}{c}\mathrm{PSP} \\
(\text { wt } \%)\end{array}$ & $\begin{array}{c}\mathrm{PSP} / \mathrm{H}_{2} \mathrm{O}_{2} \\
(\text { wt } \%)\end{array}$ \\
\hline $\mathrm{RPP}$ & 100 & - & - \\
$\mathrm{RPP} / 10 \%$ PSP & 90 & 10 & - \\
$\mathrm{RPP} / 20 \%$ PSP & 80 & 20 & - \\
$\mathrm{RPP} / 30 \%$ PSP & 70 & 30 & - \\
$\mathrm{RPP} / 40 \%$ PSP & 60 & 40 & - \\
$\mathrm{RPP} / 10 \% \mathrm{PSP} / \mathrm{H}_{2} \mathrm{O}_{2}$ & 90 & - & 10 \\
$\mathrm{RPP} / 20 \% \mathrm{PSP} / \mathrm{H}_{2} \mathrm{O}_{2}$ & 80 & - & 20 \\
$\mathrm{RPP} / 30 \% \mathrm{PSP} / \mathrm{H}_{2} \mathrm{O}_{2}$ & 70 & - & 30 \\
$\mathrm{RPP} / 40 \% \mathrm{PSP} / \mathrm{H}_{2} \mathrm{O}_{2}$ & 60 & - & 40 \\
\hline
\end{tabular}




\subsection{Measurement of Tensile Properties}

Tensile tests were carried out using a universal testing machine (Model 3366, Instron, Canton, Mass, USA) according to ASTM D638 (1994). ${ }^{8}$ Dumbbell specimens of $1 \mathrm{~mm}$ thickness were cut from the compression molded sheets with a Wallace die cutter. A crosshead speed of $5 \mathrm{~mm} / \mathrm{min}$ was used and the tests were performed at $25 \pm 3^{\circ} \mathrm{C}$. Five specimens were used to obtain the average values for tensile strength, elongation at break and tensile modulus.

\subsection{Fourier Transform Infrared (FTIR) Spectroscopy Analysis}

The functional groups and chemical characteristics of the composites were obtained by FTIR with a Perkin Elmer System 2000 (Selangor, Malaysia) at a resolution of $4 \mathrm{~cm}^{-1}$ in a spectral range of 4,000 to $550 \mathrm{~cm}^{-1}$, using 32 scans per sample.

\subsection{Morphology Evaluation}

The microstructure of the tensile fractured surfaces of the RPP/PSP and $\mathrm{RPP} / \mathrm{PSP} / \mathrm{H}_{2} \mathrm{O}_{2}$ composites were compared using a ZEISS Supra 35 VP SEM (Oberkochen, Germany). The samples were first sputter-coated with a thin layer of carbon, which provides an electron-transparent (low atomic number), conductive coating. The distribution of natural fillers and their interactions within the polymeric matrix were analysed in the captured images.

\subsection{Thermogravimetric Analysis (TGA)}

A Perkin Elmer Pyris TGA analyser was used to determine the TGA of $\mathrm{RPP} / \mathrm{PSP}$ composites. About $10 \mathrm{mg}$ of samples required in this analysis under a nitrogen atmosphere at $50^{\circ} \mathrm{C}$ to $600^{\circ} \mathrm{C}$ and $20^{\circ} \mathrm{C} / \mathrm{min}$ heating rate.

\section{RESULTS AND DISCUSSION}

\subsection{Tensile Properties}

The tensile strength, elongation at break, and tensile modulus of the RPP/PSP and RPP/PSP $/ \mathrm{H}_{2} \mathrm{O}_{2}$ composites were evaluated at different PSP loading. As can be seen from Figures 1 and 2, as PSP loading increased, the tensile strength and elongation at break decreased for both composites. The stress transferring along the applied force is disturbed by the inclusion of fillers into the polymer matrix. ${ }^{9}$ Additionally, the lack of interfacial adhesion between the fillers and the matrix exaggerated the problem. The irregular shape of the PSP fillers 
does not permit them to support the stresses transported from the polymer, which deteriorates the composites. ${ }^{10}$ The agglomeration of filler particles and drying of the polymer at the interphase also decreases the tensile strength and elongation at break. ${ }^{11}$ The high hydrophilicity of PSP restricted its incorporation into nonpolar, hydrophobic RPP. The dissimilarity in polarities deteriorated the interfacial adhesion between PSP and RPP, thus providing sites for failures to initiate and propagate.

Besides that, the treated composites presented a higher tensile strength and elongation at break than untreated composites. Alkaline peroxide treatment rises the aspect ratio and drops the filler diameter. As reported by Ray et al., during the alkaline treatment of jute fibers, the elimination of lignin and hemicellulose has an effect on the tensile characteristics of the fillers. ${ }^{12}$ The middle lamella assembly of the ultimate cell converts more flexible and homogeneous as lignin is removed. This effect is due to the slow removal of microvoids, whereas the ultimate cells themselves are exaggerated marginally, hence increasing the elongation at break of the composites. Furthermore, the interfibrillar region is probable to be less dense and less stiff after the removal of lignin and hemicellulose, permitting the fillers to rearrange themselves along the path of tensile deformation. Improved arrangements between the fillers increase load sharing as natural fillers are stressed, resulting to higher tensile strength in the fillers.

The tensile modulus clearly rises with increasing PSP loading (Figure 3). The variations in tensile modulus can be explained by the stiffening effect of the PSP. The presence of rigid filler particles in the soft matrix develops the stiffness of composite materials. ${ }^{10,13,14}$ When comparing both composites, the treated composites had a slightly higher tensile modulus than the untreated composites. There are few factors that could have affected the tensile modulus of treated composites, such as aspect ratio and degree of molecular orientation. In this case, the higher tensile modulus of the treated PSP might have been due to the welloriented cellulosic fillers, which could increase stiffness and result in a higher tensile modulus. 


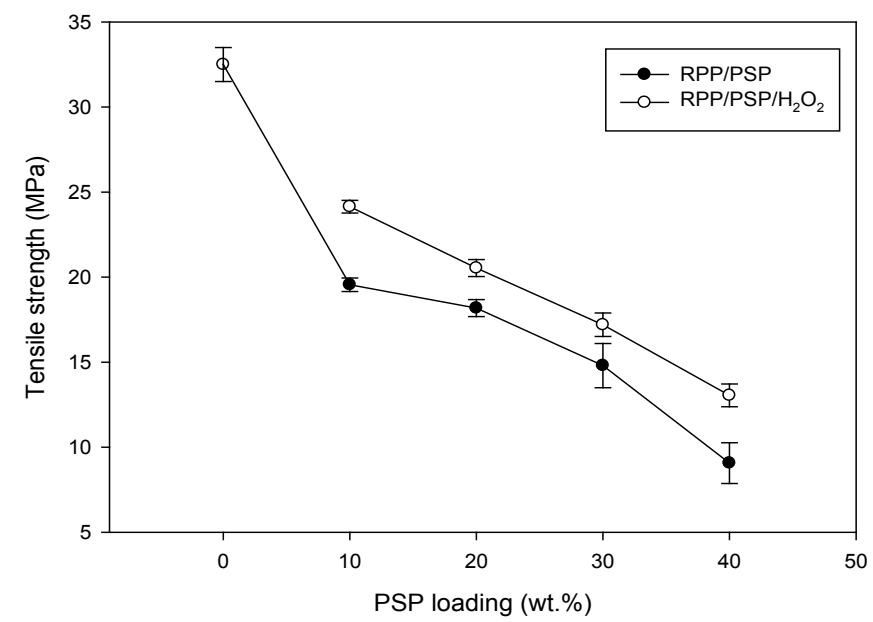

Figure 1: Tensile strength of RPP/PSP and RPP/PSP/ $\mathrm{H}_{2} \mathrm{O}_{2}$ at different PSP loading.

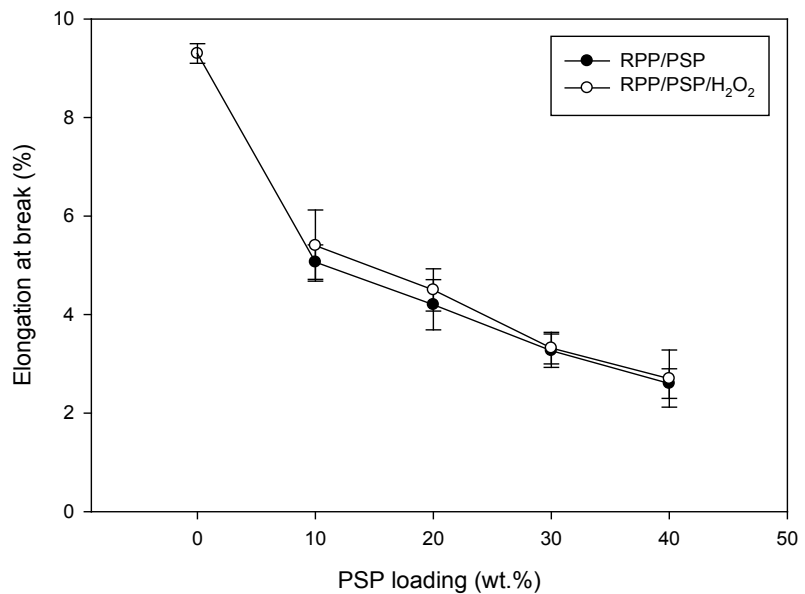

Figure 2: Elongation at break of RPP/PSP and RPP/PSP/ $/ \mathrm{H}_{2} \mathrm{O}_{2}$ at different PSP loading. 


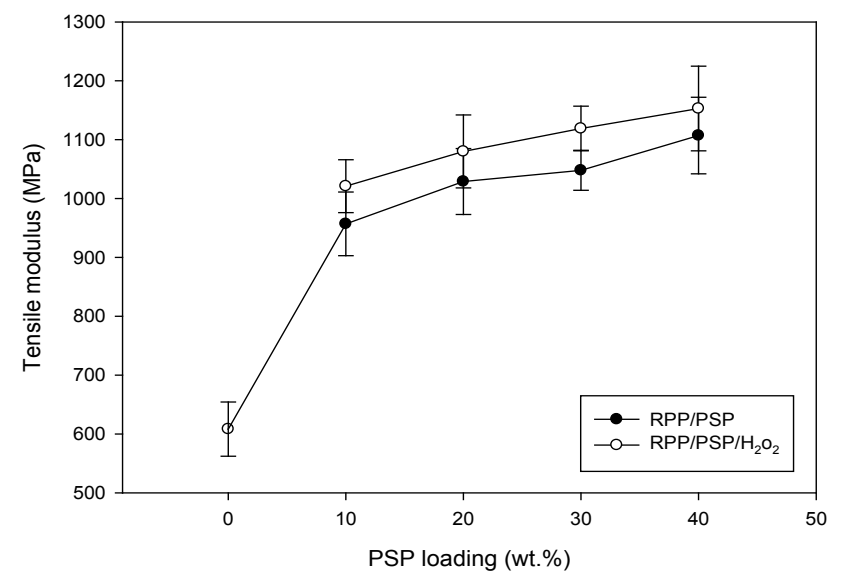

Figure 3: Tensile modulus of RPP/PSP and RPP/PSP/ $\mathrm{H}_{2} \mathrm{O}_{2}$ at different PSP loading.

\subsection{Fourier Transform Infrared (FTIR) Spectroscopy Analysis}

FTIR spectra of the RPP/PSP and RPP/PSP/ $\mathrm{H}_{2} \mathrm{O}_{2}$ composites was shown in Figure 4. The first band was centred between $2,909.2$ and $2,932.31 \mathrm{~cm}^{-1}$, predominantly arising from the $\mathrm{C}-\mathrm{H}$ stretching in aromatic methoxyl groups. There was a notable absence of the absorbance peak at $1,740 \mathrm{~cm}^{-1}$, which is due to the ester carbonyl vibration in acetyl, feruloyl, p-coumaroyl, etc. groups in lignin and hemicelluloses. ${ }^{15}$ The stretching peaks at about $1,654 \mathrm{~cm}^{-1}$ originated from conjugated $\mathrm{C}-\mathrm{C}$ stretching, indicating that there is an ester bond between hydroxycinnamic acids and lignin, while at $1,461 \mathrm{~cm}^{-1}$, the band represented $\mathrm{C}-\mathrm{H}$ stretching in $\mathrm{CH}_{2}$ and $\mathrm{CH}_{3}$. Alkaline peroxide treatment did not have any dramatic effect on lignin structure, except for an increase in carboxylic acid content and a decrease in phenolic hydroxyl content, which was indicated by a relative increase in carbonyl group stretching from 1,256 to $1,133 \mathrm{~cm}^{-1}$. The introduction of carboxyl groups into lignin is important because this functional group is hydrophilic and facilitates dissolution in water. ${ }^{16}$ 


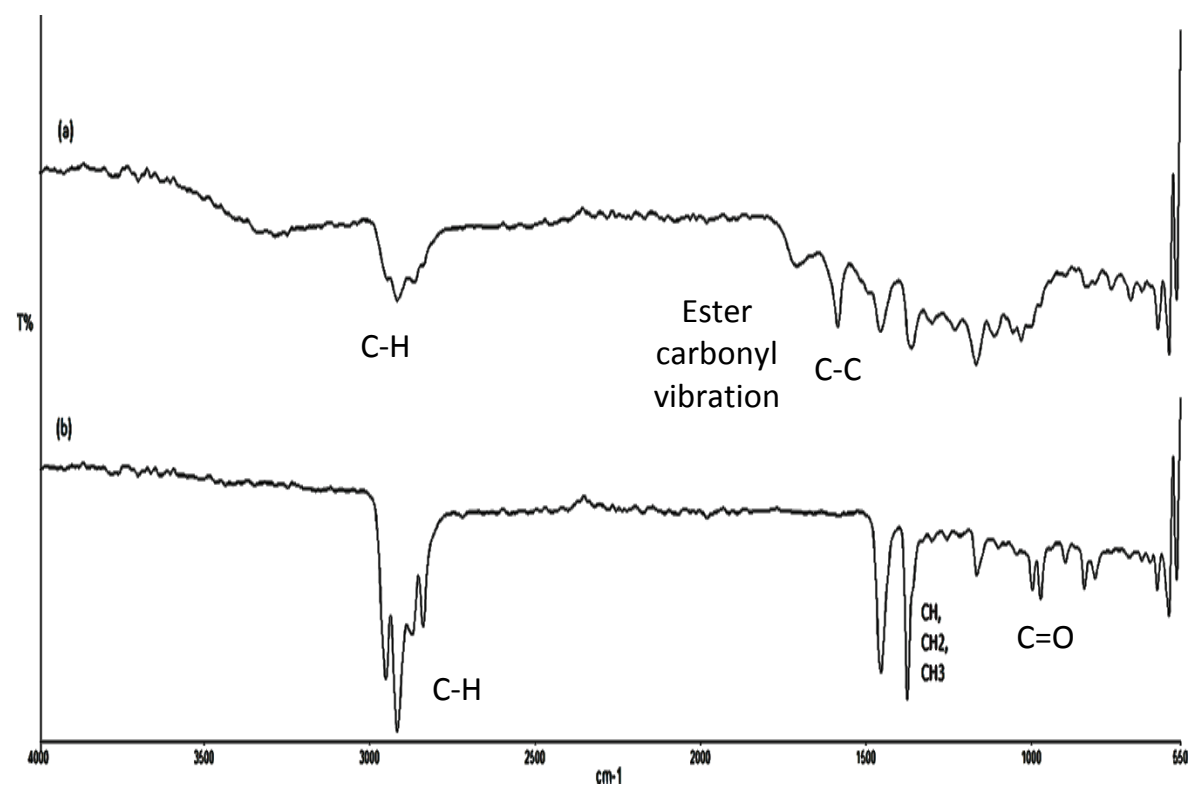

Figure 4: IR spectra of (a) RPP/PSP and (b) RPP/PSP/ $\mathrm{H}_{2} \mathrm{O}_{2}$ composites.

\subsection{Morphology Evaluation}

Scanning electron microscopy was implemented to observe the tensilefractured surfaces of the RPP/PSP and RPP/PSP $/ \mathrm{H}_{2} \mathrm{O}_{2}$ composites at 10 and 40 wt \% PSP loading (Figures 5 and 6). Figure 5(a) displays a rough surface of untreated composites. A more porous structure and filler agglomeration were detected for composites at higher filler loadings in Figure 5(b). The porosity of the structure was due to the low adhesion of the filler and the matrix, which decreased tensile strength by permitting the fillers to be removed easily from the composites. The pores or voids are defects concentrate stress locally during deformation. Hence, premature failure of the composites occurred at higher filler content, indicating lower tensile strength. High filler loading can result in agglomeration, which is detrimental to the mechanical properties. ${ }^{17}$

For composites with treated PSP, a smoother fractured surface was observed in Figure 6(a). Alkaline peroxide pre-treatment had an effect on fillermatrix adhesion. Better interfacial adhesion between the treated PSP filler and the RPP matrix can be seen clearly in Figure 6(b). The interfacial adhesion might have been improved by the removal of lignin during pre-treatment. The removal of the lignin breaks down the filler bundles, thus exposing more hydroxyl and carbonyl groups on the surface. 

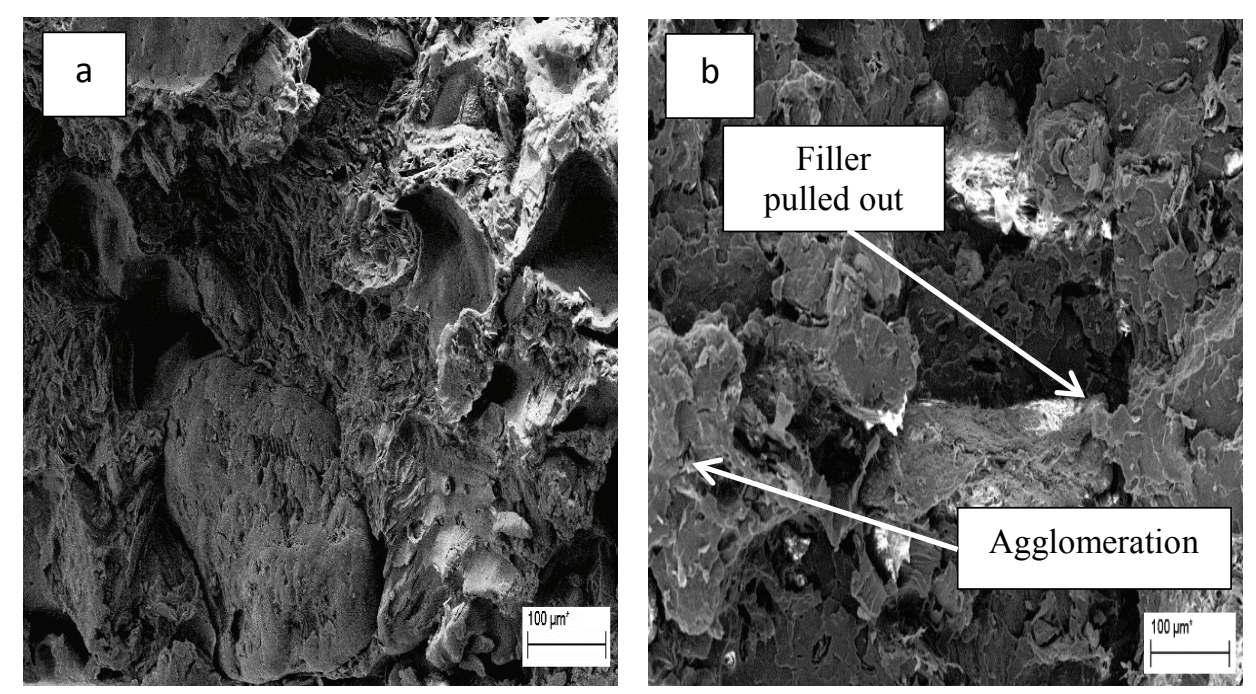

Figure 5: SEM micrographs of RPP/PSP composites at (a) $10 \mathrm{wt} \%$ and (b) $40 \mathrm{wt} \%$ PSP loading.
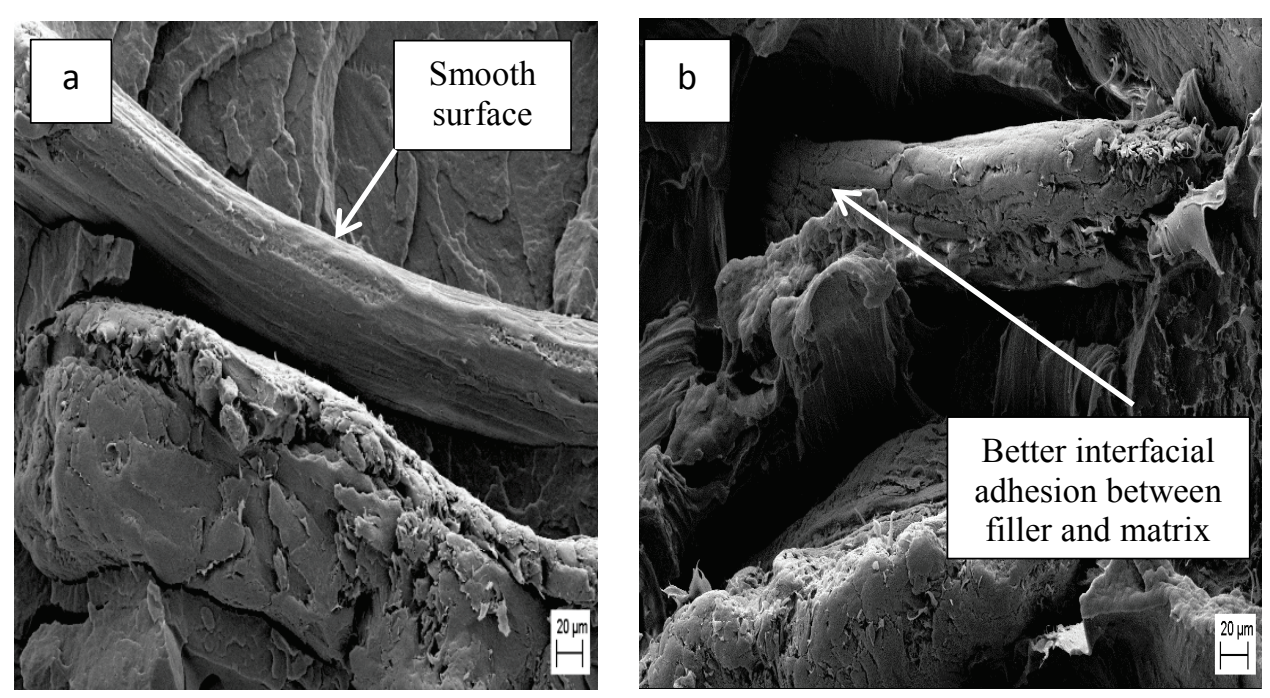

Figure 6: SEM micrographs of RPP/PSP $/ \mathrm{H}_{2} \mathrm{O}_{2}$ composites at (a) $10 \mathrm{wt} \%$ and (b) $40 \mathrm{wt} \%$ PSP loading.

\subsection{Thermogravimetric Analysis}

Generally, thermogravimetric analysis of the composite was carried out to assess its thermal stability and degradation temperature. Figures 7 and 8 are the representative of thermogravimetric (TG) and derivative thermogravimetric (DTG) profiles of RPP/PSP and RPP/PSP/ $\mathrm{H}_{2} \mathrm{O}_{2}$ composites at different PSP 
loading. As evidenced by thermograms in Figure 7, all composite samples experienced three stages of weight losses; first region $\left(130^{\circ} \mathrm{C}-190^{\circ} \mathrm{C}\right)$, second region $\left(200^{\circ} \mathrm{C}-400^{\circ} \mathrm{C}\right.$ ), and third region (above $400^{\circ} \mathrm{C}$ ). Around $130^{\circ} \mathrm{C}-190^{\circ} \mathrm{C}$, the TGA result displays the elimination of intrinsically absorbed water in the composites. Besides that, the decomposition temperature in the range $200^{\circ} \mathrm{C}$ $400^{\circ} \mathrm{C}$ demonstrates the thermal degradation of hemicellulose and cellulose while above $400^{\circ} \mathrm{C}$ belongs to the decomposition temperature of lignin and RPP. This is reliable with outcomes stated by Monteiro et al. in their studies on thermogravimetric stability of polymer composites/lignocellulosic fibers. ${ }^{18}$

The TGA data of RPP/PSP and RPP/PSP $/ \mathrm{H}_{2} \mathrm{O}_{2}$ composites were summarised in Table 2. The $\mathrm{T}_{5 \%}, \mathrm{~T}_{30 \%}, \mathrm{~T}_{50 \%}$ and $\mathrm{T}_{70 \%}$ represent the degradation temperature at $5 \%, 30 \%, 50 \%$ and $70 \%$ sample weight loss, respectively. For untreated PSP (at $10 \mathrm{wt} \% \mathrm{PSP}$ ), the degradation temperature at $5 \%$ weight loss is $261^{\circ} \mathrm{C}$ whereas the final degradation temperature at $70 \%$ weight loss is $376^{\circ} \mathrm{C}$. Similarly, for treated PSP (at $10 \mathrm{wt} \%$ PSP), the degradation temperature at $5 \%$ weight loss has been found to be $345^{\circ} \mathrm{C}$ whereas the degradation temperature at $70 \%$ weight loss has been found to be $464^{\circ} \mathrm{C}$. It seems that, the RPP $/ \mathrm{PSP} / \mathrm{H}_{2} \mathrm{O}_{2}$ composites results in better thermal stability compared to RPP/PSP composites. This can be explained on the basis that the filler becomes more amorphous upon grafting due to disruption of the crystalline lattice of the filler. ${ }^{19}$ Pre-treatment PSP with alkaline peroxide seems to enhance the interaction between the filler and the RPP matrix which cause better dispersion of PSP particles in the composites. These ultimately resulted in the increases of thermal stability.

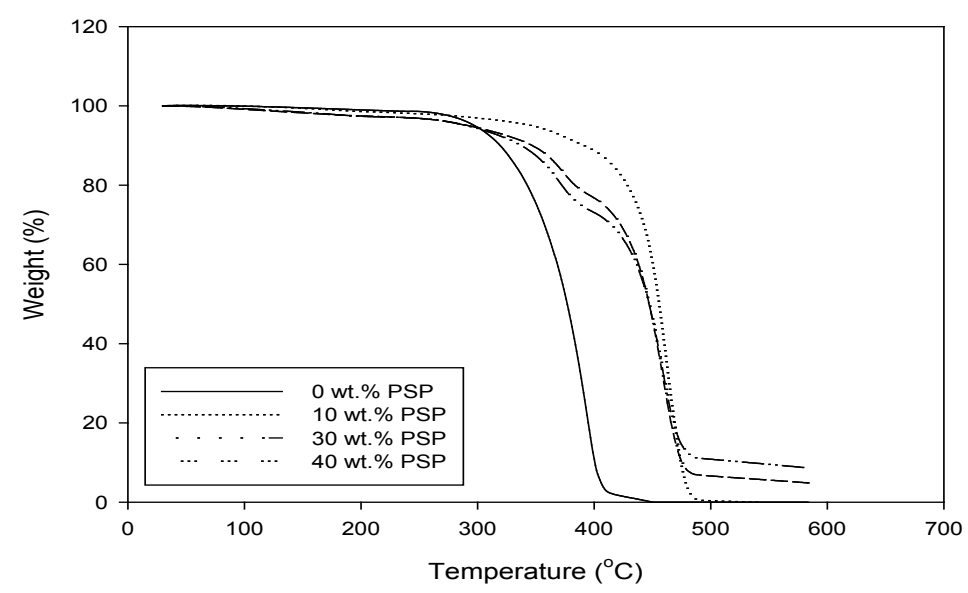

Figure 7: TG thermograms of RPP/PSP/ $\mathrm{H}_{2} \mathrm{O}_{2}$ composites. 


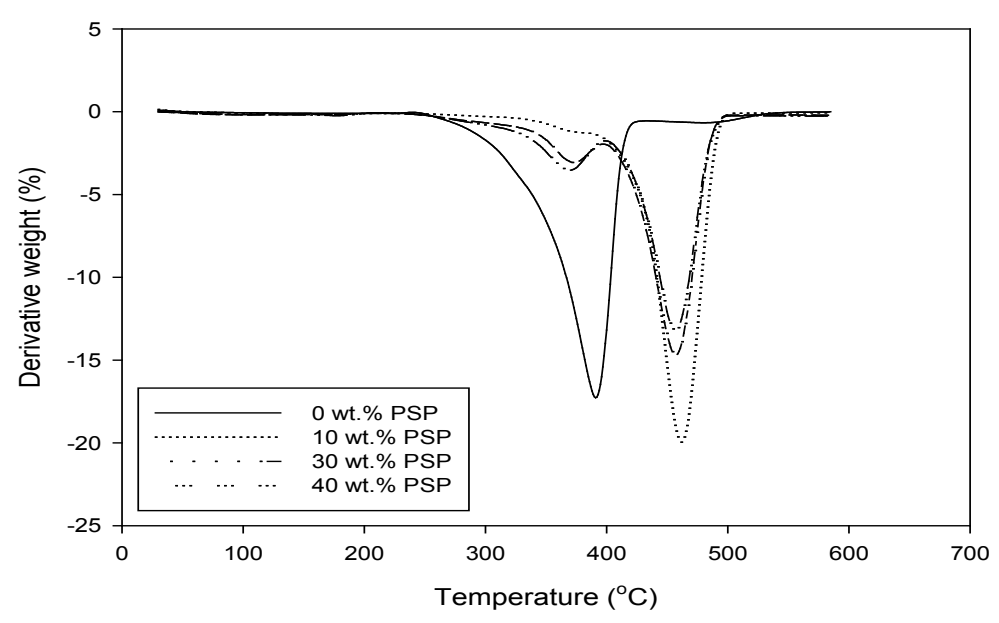

Figure 8: DTG thermograms of RPP/PSP/ $\mathrm{H}_{2} \mathrm{O}_{2}$ composites.

Table 2: TGA data of RPP/PSP and RPP/PSP/ $\mathrm{H}_{2} \mathrm{O}_{2}$ composites.

\begin{tabular}{lllll}
\hline Sample & $\mathrm{T}_{5 \%}\left({ }^{\circ} \mathrm{C}\right)$ & $\mathrm{T}_{30 \%}\left({ }^{\circ} \mathrm{C}\right)$ & $\mathrm{T}_{50 \%}\left({ }^{\circ} \mathrm{C}\right)$ & $\mathrm{T}_{70 \%}\left({ }^{\circ} \mathrm{C}\right)$ \\
\hline $\mathrm{RPP}$ & 297 & 357 & 376 & 390 \\
$\mathrm{RPP} / 10 \%$ PSP & 261 & 300 & 354 & 376 \\
$\mathrm{RPP} / 30 \%$ PSP & 239 & 298 & 344 & 352 \\
$\mathrm{RPP} / 40 \%$ PSP & 220 & 286 & 302 & 322 \\
$\mathrm{RPP} / 10 \%$ PSP $/ \mathrm{H}_{2} \mathrm{O}_{2}$ & 345 & 442 & 455 & 464 \\
$\mathrm{RPP} / 30 \%$ PSP $/ \mathrm{H}_{2} \mathrm{O}_{2}$ & 291 & 423 & 448 & 461 \\
$\mathrm{RPP} / 40 \%$ PSP $/ \mathrm{H}_{2} \mathrm{O}_{2}$ & 290 & 415 & 447 & 460 \\
\hline
\end{tabular}

\section{CONCLUSION}

i. Treated RPP/PSP/ $\mathrm{H}_{2} \mathrm{O}_{2}$ composites showed an improvement in tensile strength, elongation at break, and tensile modulus compared to untreated RPP/PSP composites.

ii. IR spectra and SEM micrographs showed that the elimination of lignin strongly influenced the fractured surface and the chemical characteristics of treated RPP/PSP $/ \mathrm{H}_{2} \mathrm{O}_{2}$ composites.

iii. Treated $\mathrm{RPP} / \mathrm{PSP} / \mathrm{H}_{2} \mathrm{O}_{2}$ composites results in better thermal stability compared to untreated RPP/PSP composites. 


\section{ACKNOWLEDGEMENT}

The authors would like to acknowledge the financial support provided by MyBrain15 from the Ministry of Education of Malaysia.

\section{REFERENCES}

1. Nabi Saheb, D. \& Jog, J. P. (1999). Natural fiber polymer composites: A review. Adv. Polym. Technol., 18(4), 351-363, https://doi.org/10.1002/(SICI)1098-2329(199924)18:4<351::AIDADV6>3.0.CO;2-X.

2. George, J., Sreekala, M. S. \& Thomas, S. (2001). A review on interfacial modification and characterization of natural fiber reinforced plastic composites. Polym. Eng. Sci., 41(9), 1471-1485, https://doi.org/ 10.1002/pen.10846.

3. Li, Y., Mai, Y. W. \& Ye, L. (2000). Sisal fibre and its composites: A review of recent developments. Compos. Sci. Technol., 60(11), 2037 2055, https://doi.org/10.1016/S0266-3538(00)00101-9.

4. Agrawal, N. S. et al. (2000). Activation energy and crystallization kinetics of untreated and treated oil palm fiber reinforced phenol formaldehyde composites. Mater. Sci. Eng., A, 277(1-2), 77-82, https://doi.org/10.1016/S0921-5093(99)00556-0.

5. John, M. J. et al. (2008). Effect of chemical modification on properties of hybrid fiber biocomposites. Composites, Part A, 39(2), 352-363, https://doi.org/10.1016/j.compositesa.2007.10.002.

6. Sreekala, M. S., Kumaran, M. G. \& Thomas, S. (1997). Oil palm fibers: Morphology, chemical composition, surface modification, and mechanical properties. J. Appl. Polym. Sci., 66(5), 821-835, https://doi.org/10.1002/(SICI)1097-4628(19971031)66:5<821::AIDAPP2>3.0.CO;2-X.

7. Mukherjee, A., Ganguly, P. K. \& Sur, D. (1993). Structural mechanics of jute: The effects of hemicellulose or lignin removal. J. Text. Inst., 84(3), 348-353, https://doi.org/10.1080/00405009308658967.

8. Obasi, H. C., Igwe, I. O. \& Madufor, I. C. (2013). Effect of soil burial on tensile properties of polypropylene/plasticized cassava starch blends. Adv. Mater. Sci. Eng., 2013, 1-5, https://doi.org/10.1155/2013/326538.

9. Pracella, M. et al. (2006). Functionalization, compatibilization and properties of polypropylene composites with hemp fibres. Compos. Sci. Technol., 66(13), 2218-2230, https://doi.org/10.1016/j.compscitech. 2005.12.006.

10. Cao, X. V. et al. (2011). Mechanical properties and water absorption of kenaf powder filled recycled high density polyethylene/natural rubber 
biocomposites using MAPE as a compatibilizer. BioResources, 6(3), 3260-3271.

11. Ismail, H., Nizam, J. M. \& Abdul Khalil, H. P. S. (2001). The effect of a compatibilizer on the mechanical properties and mass swell of white rice hulk ash filled natural rubber/linear low density polyethylene blends. Polym. Test., 20(2), 125-133, https://doi.org/10.1016/S01429418(00)00013-1.

12. Ray, D. et al. (2001). The mechanical properties of vinylester resin matrix composites reinforced with alkali-treated jute fibres. Composites, Part A, 32(1), 119-127, https://doi.org/10.1016/S1359-835X(00)001019.

13. Abdul Khalil, H. P. S. et al. (2001). The effect of anhydride modification of sago starch on the tensile and water absorption properties of sago filled linear low density polyethylene (LLDPE). Polym.-Plast. Technol. Eng., 40(3), 249-263, https://doi.org/10.1081/PPT-100000246.

14. Ismail, H., Abdullah, A. H. \& Bakar, A. A. (2011). Influence of acetylation on the tensile properties, water absorption, and thermal stability of (high density polyethylene)/(soya powder)/(kenaf core) composites. J. Vinyl Addit. Technol., 17(2), 132-137, https://doi.org/10.1002/vnl.20262.

15. Sun, R. C. et al. (2002). Structural and physico-chemical characterization of lignins solubilized during alkaline peroxide treatment of barley straw. Eur. Polym. J., 38(7), 1399-1407, https://doi.org/10.1016/S00143057(01)00303-2.

16. Sun, R. C., Tomkinson, J. \& Jun, Y. (2003). Physico-chemical and structural characterization of residual lignins isolated with TAED activated peroxide from ultrasound irradiated and alkali pre-treated wheat straw. Polym. Degrad. Stab., 79(2), 241-251, https://doi.org/10.1016/ S0141-3910(02)00287-2.

17. Gauthier, R. et al. (1998). Interfaces in polyolefin/cellulosic fiber composites: Chemical coupling, morphology, correlation with adhesion and aging in moisture. Polym. Compos., 19(3), 287-300, https://doi.org/10.1002/pc.10102.

18. Monteiro, S. N. et al. (2012). Thermogravimetric stability of polymer composites reinforced with less common lignocellulosic fibers: An overview. J. Mater. Res. Technol., 1(2), 117-126, https://doi.org/10.1016/S2238-7854(12)70021-2.

19. Kalia, S., Kaith, B. S. \& Kaur, I. (2009). Pretreatments of natural fibers and their application as reinforcing material in polymer composites: A review. Polym. Eng. Sci., 49(7), 1253-1272, https://doi.org/10.1002/pen.21328. 